\title{
Comparative Dynamics of DNA Isolated from Buccal Swab for Forensic Investigation "Pro and Post Brushing from Some Adult Males in Benin Metropolis, Nigeria"
}

\author{
Ibeh Nnanna Isaiah ${ }^{* 1}$ and Minari Bamidele Joseph ${ }^{2}$ \\ ${ }^{1}$ Department of Health Services, University of Benin, Benin City, Nigeria \\ ${ }^{2}$ Department of Cell Biology and Genetics, University of Lagos, Nigeria
}

${ }^{*}$ Corresponding author: Ibeh Nnanna Isaiah, Department of Health Services, University of Benin, Benin City, Nigeria, E-mail: nnanma.ibeh@uniben.edu

Citation: Ibeh Nnanna Isaiah and Minari Bamidele Joseph (2016) Comparative Dynamics of DNA Isolated from Buccal Swab for Forensic Investigation "Pro and Post Brushing from Some Adult Males in Benin Metropolis, Nigeria”. J Forensic Sci Criminol 4(5) : 501. doi: 10.15744/2348-9804.4.501

Received Date: September 10, 2016 Accepted Date: December 27, 2016 Published Date: December 29, 2016

\begin{abstract}
The present study was performed to determine the quality and the quantity of DNA extracted from buccal swab at two intervals to compare the DNA quality and quantity before and after brushing. Five (5) healthy males where used in the study, ten (10) Buccal swabs where collected at two intervals, five (5) before brushing and five (5) after brushing commonly available samples and to estimate the DNA yield and purity from the various times of collection. The purity and the concentration of the extracted DNA were determined spectrophotometric analysis, and the adequacy of DNA extracts for the PCR-based assay was assessed by amplifying a 1030-bp region of the mitochondrial D-loop. Although DNA from all the intervals was suitable for PCR, the samples before brushing when the mouth was empty provided a good quality DNA for restriction analysis of the PCR product compared with the buccal swab after brushing. In the present study, buccal swab samples showed to be a good source of genomic DNA for PCR-based methods.
\end{abstract}

Keywords: Spectrophotometric; Mitochondrial; Genomics; Buccal

\section{Introduction}

Deoxyribonucleic acid (DNA) can be successfully extracted from many biological sources such as blood, semen, saliva, buccal cells and skin cells. This DNA can then be amplified using polymerase chain reaction (PCR) to create DNA profiles which could be used to help convict or exonerate a suspect in a criminal case; therefore DNA is vitak in forensic science [1-6]. Extraction methods not only have to remove inhibitors which may interfere with subsequent downstream processes, for example, blood contains haem which is a PCR inhibitor and therefore this must be sufficiently removed during the extraction processes to allow the DNA to be amplified both organic and inorganic methods of DNA extraction are available, each giving variable results depending on the sample type [7-9].

For this reason several protocols have been developed to obtain DNA from buccal cells. The collection of buccal cells by mouthwash seems to give higher yields than many other methods [10-12]. The diagnostic results obtained with DNA from buccal cells are compatible with whole blood [13,14]. Several approaches have been developed to isolate DNA from mouth- washes [15-20]. The more frequently used are: a) boiling lysis method, yielding poor-quality DNA phenol- chloroform, which is laborious and uses toxic reagents commercially available kits, which are non- toxic and simple to use [21-23]. Although the use of kits is more straightforward they may be quite expensive.

Several researches on buccal DNA isolation has been carried out but not all has centred on the purity of the DNA extracted from the comparative studies on buccal samples from patients before and after brushing. This is to compare the quantity, quality and the purity of the buccal DNA extracted, using adult male from Benin metropolis, Edo state South Southern Nigeria as a case study. This work was thus carried out to provide a bridge for the gap of information on buccal DNA extraction [24-30]. 


\section{Materials and Method}

\section{Study Subject}

The study population comprised of Five (5) healthy males for the comparative analysis of buccal samples for DNA isolation at varied time of collection.

\section{Study Sample}

Sample of study is the buccal sample for the isolation of human DNA.

\section{Sample Collection}

In the current study, Five (5) healthy adult males volunteers were recruited (age range, 22-35 years), and demographic information, including age, health condition, sex, population ancestry, was collected. The volunteers recruited were asked to collect buccal samples twice, the first just as they wake up in the morning this is to compare if the effect the effect of mouth gaggling with water, the other after they rinse their mouth with tap water, 30 seconds before sampling of buccal swabs [31-34]. For each individual, both sides of buccal mucosa were wiped with a cotton swab for 15 seconds, and a total of five samples was collected in $500 \mu 10 \mathrm{M}$ Tris- $\mathrm{HCl}, 10 \mathrm{mM}$ EDTA, 2\% SDS, containing 1.5-ml microcentrifuge tubes. Isolation of DNA from cotton swabs was performed (vide infra).

\section{DNA Extraction from Buccal Sample}

The samples were analysed almost 1 hour after collection. The buccal swab samples were suspended in $500 \mu \mathrm{llysis}$ buffer [10 mM Tris (pH 8.0), $10 \mathrm{mM}$ EDTA, and 2.0\% SDS], and $50 \mu \mathrm{l} 10 \% \mathrm{SDS}$, followed by 5-10 $\mu \mathrm{l} 20 \mathrm{mg} / \mathrm{ml}$ proteinase K (Himedia, Mumbai, India), was added $[35,36]$. The samples were incubated $1-3 \mathrm{~h}$ at $56^{\circ} \mathrm{C}$ until the tissue was totally dissolved.

The DNA would be extracted from each sample with an equal volume of phenol:chloroform: isoamyl alcohol solution (25:24:1) and mixed gently by inverting the tubes for $3 \mathrm{~min}$. The samples were then centrifuged (Eppendorf 5415R; Hamburg, Germany) for 10 min with $10,000 \mathrm{~g}\left(4^{\circ} \mathrm{C}\right)$, and the upper aqueous layer was transferred to a fresh, sterilized microcentrifuge tube. RNase A (10 $\mu \mathrm{l}$ of $10 \mathrm{mg} / \mathrm{ml}$; Fermentas, Thermo Scientific, Germany) was added, and the solution was incubated at $37^{\circ} \mathrm{C}$ for $30 \mathrm{~min}[36-40]$. Equal volumes of chloroform:isoamyl alcohol solution were added and centrifuged (Eppendorf $5415 \mathrm{R})$, again with $10,000 \mathrm{~g}\left(4^{\circ} \mathrm{C}\right)$ for $10 \mathrm{~min}$.

The upper aqueous layer was transferred to a sterilized micro-centrifuge tube, and double the volume of chilled isopropanol (Merck, Whitehouse Station, NJ, USA) was added, along with one-tenth volume of $3 \mathrm{M}$ sodium acetate, and chilled at $-20^{\circ} \mathrm{C}$ for 1 $\mathrm{h}$ for precipitation. After $1 \mathrm{~h}$, the sample was centrifuged (Eppendorf 5415R) at 10,000 $\mathrm{g}\left(4^{\circ} \mathrm{C}\right)$ for $10 \mathrm{~min}$ [41-44]. After decanting the supernatant, $250 \mu \mathrm{l} 70 \%$ ethanol (Merck) was added, and the pellet was dissolved; the mixture was centrifuged at 10,000 rpm for $10 \mathrm{~min}$, and the supernatant was decanted gently. The pellet was air-dried under laminar air flow, and the dried pellet was resuspended in $50 \mu \mathrm{l}$ nuclease-free water or $1 \times 10 \mathrm{mM}$ Tris- $\mathrm{HCl}, 1 \mathrm{mM}$ EDTA, $\mathrm{pH} 7.6(\mathrm{TE})$, buffer and frozen at $-20^{\circ} \mathrm{C}$ or at $-80^{\circ} \mathrm{C}$ for storage [45-49].

\section{Concentration and Purity Determination}

A quantitative spectrophotometric assay of DNA was performed using a Cary 60 UV-visible spectrophotometer (Agilent Technologies, Santa Clara, CA, USA). Absorbance was measured at wavelengths of 260 and $280\left(\mathrm{~A}_{260}\right.$ and $\mathrm{A}_{280}$, respectively) nm. The absorbance quotient $\left(\mathrm{OD}_{260} / \mathrm{OD}_{280}\right)$ provides an estimate of DNA purity. An absorbance quotient value of $1.8<$ ratio $(\mathrm{R})<2.0$ was considered to be good, purified DNA. A ratio of $<1.8$ is indicative of protein contamination, where as a ratio of $>2.0$ indicates RNA contamination.

\section{DNA Integrity}

The integrity of genomic DNA was tested by resolving DNA extracts on a $0.8 \%$ agarose gel by electrophoresis (Bio-Rad, Hercules, CA, USA), followed by visualization with ethidium bromide staining. Each DNA sample was graded, according to the electrophoretic migration of sample DNA compared with a known molecular weight marker (Fermentas, Thermo Scientific) [50-53].

\section{PCR Amplification of mtDNA D-Loop Region for PCR-Based Assays}

The adequacy of buccal, DNA extracts for the PCR-based assays was assessed by amplifying the mtDNA D-loop region, which was amplified by PCR using primers human mitochondrial (HMt)-F (5'-CACCATTAGCACCCAAAGCT-3') and HMt-R (5'-CTGTTAAAAGTGCATACCGCCA-3'), as described by Salas, et al. for the HVI region. PCR (vapo.protect; Eppendorf) was carried out in $25 \mu$ total reaction volumes, each containing 100 ng template DNA, 0.2 pM of each primer, $2.5 \mu l 10 \times$ PCR buffer (final $1 \times$ PCR buffer), $1.5 \mathrm{mM} \mathrm{MgCl} 2,200 \mathrm{mM}$ dNTPs, and 1 unit Taq DNA polymerase [28,29,30]. The reaction mixture was heated to $94^{\circ} \mathrm{C}$ for $5 \mathrm{~min}$, followed by 40 cycles, each consisting of $1 \mathrm{~min}$ denaturation at $94^{\circ} \mathrm{C}, 1 \mathrm{~min}$ annealing at $63^{\circ} \mathrm{C}, 1.5 \mathrm{~min}$ extension at $72^{\circ} \mathrm{C}$, and a final 10 -min extension at $72^{\circ} \mathrm{C}$. The PCR amplification products $(10 \mu \mathrm{l})$ were subjected to electrophoresis (Bio-Rad) on 1.2\% agarose gel in $1 \times$ Tris-acetate-EDTA buffer at $80 \mathrm{~V}$ for $30 \mathrm{~min}$ and stained with ethidium bromide (Himedia), and images were obtained in gel documentation (G-Box; Syngene, Cambridge, UK) systems. 


\section{Statistical Analysis}

The statistical analysis would be carried out using $c h i^{2}$ square with the SPSS software and anova for comparative analysis on DNA isolation over time using the Power value of $(\mathrm{P}<0.05)$.

\section{Results}

\section{DNA Yield}

In this study the DNA yield obtained from the buccal swab from the first interval which is before rinsing as shown in table 1, DNA yield ranged from $62-85 \mathrm{ng} / \mu \mathrm{l}$ and the after brushing which ranged from $66-82 \mathrm{ng} / \mu \mathrm{l}$ respectively.

\begin{tabular}{|c|c|c|c|c|}
\hline & \multicolumn{2}{|c|}{ DNA YIELD $(\mathbf{n g} / \boldsymbol{\mu l})$} & \multicolumn{2}{c|}{ DNA QUALITY (AB: 260/280) } \\
\hline & BEFORE & AFTER & BEFORE & AFTER \\
\hline S1 & 83 & 78 & 1.72 & 1.82 \\
\hline S2 & 62 & 66 & 1.82 & 1.78 \\
\hline S3 & 85 & 82 & 1.64 & 1.62 \\
\hline S4 & 66 & 68 & 1.76 & 1.82 \\
\hline S5 & 76 & 70 & 1.86 & 1.78 \\
\hline
\end{tabular}

Key: $\mathrm{AB}=$ absorbance, $\mathrm{S}=$ student

S1-study subject one; S2-study subject two; S3-study subject three; S4-study subject four; S5-study subject five

Table 1: Showing comparative DNA yield and quality

From the first interval the highest yield of DNA was from the study subject three (S3) with $85 \mathrm{ng} / \mu \mathrm{l}$ and the lowest was from study subject two (S2) $62 \mathrm{ng} / \mu \mathrm{l}$ all shown in table 1. From the second interval the highest yield was from the study subject (S3) with 82 $\mathrm{ng} / \mu \mathrm{l}$ and the lowest was Subject two (S2) with $66 \mathrm{ng} / \mu \mathrm{l}$ respectively. The comparative mean DNA yield of before and after showed that before was higher that after $(74.4 \pm 4.5$ and $72.8 \pm 3.0)$ as shown in table 2 .

\begin{tabular}{|c|c|c|c|}
\hline & BEFORE & AFTER & pvalue \\
\hline DNA YIELD ng/ $\mu \mathrm{l}$ & $74.4+4.5$ & $72.8+3.0$ & 0.09 \\
\hline $\begin{array}{c}\text { SPECTROPHOTOMETRIC } \\
\text { ANALYSIS (AB 260/280) }\end{array}$ & $1.76+0.03$ & $1.76+0.03$ & 0.00 \\
\hline
\end{tabular}

Key: $\mathrm{AB}=$ absorbance

Table 2: The mean comparative analysis of the study subjects

\section{DNA Quality}

The DNA quality was measured using the UV spectrophotometric analyser with a wavelength of 260 and 280 . The DNA quality from the first interval ranges from 1.64-1.87 and the second interval ranging from 1.62-1.82 respectively. Subject five (S5) showed the highest with an absorbance of 1.87 and Subject three (S3) with an absorbance of 1.64. Subject one and four (S1 and S4) in the second interval had the highest absorbance (1.82 and 1.82), the lowest was also observed in study subject three (S3) 1.62.

From the first interval there were bands of degradation shown on the gel electrophoresis, Subject one and three, (S1 and S3) shown in plate 1.0. Subject two, four and five (S2,4 and 5) showed bands of degradation in the second interval as shown in plate 2.0

\section{Discussion}

The use of buccal swab for DNA extraction in forensic investigation depends on a lot factors which may alter the purity and quality of the DNA, it might be moderately or highly altered depending on the individual being swabbed, the swabbing technique and the number of cells captured [50-52]. In this study the DNA yield obtained from the buccal swab from the first interval shown in table 1 the DNA yield which ranged from $62-85 \mathrm{ng} / \mu \mathrm{l}$ is in consonant with a previous study on buccal DNA yield with $60-85 \mathrm{ng} / \mu \mathrm{l}$ which was carried out to measure the DNA yield from buccal cells on different intervals [24,25]. As observed from the first interval there was no significant decrease in DNA quality and quantity $(\mathrm{p}<0.05)$ which is suggestive that cell lysis buffer during processing can distort the quality and quantity of DNA as described by $[33,34]$. The DNA quality as observed on both intervals with an absorbance quotient of $1.8<$ ratio $<2.0$ was considered to be good or purified DNA [24]. In this study our lowest absorbance was 1.62 and the highest 1.87, which suggest that the DNA extracted from both intervals were pure or considered to be good [54]. The DNA quality from both interval showed no observable difference with their mean absorbance of $1.76+0.03$ and $1.76+0.03$ respectively this is suggestive that DNA can be extracted from both intervals and that brushing does not affect the quality of DNA which is in tandem with a previous work done by which establishes that brushing or mouth gaggling does not have any significance on DNA quality from buccal cell $[18,19,22,26]$. 
The bands of degradation observed in the first interval and second intervals of collection which (S1 and S3), (S2,S4 and S5) as shown in Figure 1, which shows the comparative quality of the DNA extracted, the distortion might be as a result of contamination of the DNA or due to the extent of nuclease enzyme concentration in the samples before digestion which is explained by [24].

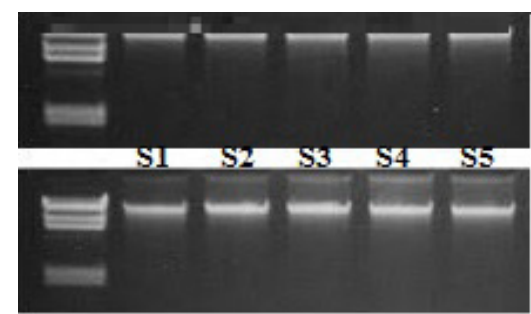

Plate 1- Before brushing; Plate 2- After brushing

S1-study subject one; S2-study subject two; S3-study subject three; S4-study subject four; S5-study subject five

Figure 1: The PCR Amplificaion for mtDNA Loop Region 1030bp from the five study subjects

The present study did not exhibit any significant difference between the extracted DNA PCR amplification products. However processing samples immediately as observed in this study may increase the quality of DNA extracted as a delay may contradict forensic investigation [24]. The isolated DNA from the study group generated PCR products of the same base-pair size of the target mitochondrial gene, the restriction digestion of the PCR products produced good digested products. This may be a result of the presence of good concentration of PCR amplification products and the absence of any impurity in the PCR.

The successful sample collection and the extraction of genomic DNA from buccal swabs in this study where non-invasive and reliable alternatives to the prickly invasive blood sampling techniques as observed by previous contributors [26,34].

The buccal swab collected from both intervals yielded desirable DNA extracts and when compared with the primer amplification product yielded same base pair size and so DNA can be extracted at both intervals irrespective of brushing or mouth gaggling as it possess no effect on DNA quality and yield, as impurity affects the reliability and authenticity of the DNA extracted [52-54].

\section{Conclusion}

Buccal cell DNA quality is of great importance in solving and investigating events in Forensic biology. The quality and quantity of DNA extracted is dependent on factors which may be both intrinsic and extrinsic, the mode of collection, extraction and aseptic techniques during amplification. An empty mouth is still of better preference when collecting buccal swab DNA as food in the mouth may cause contamination. Brushing does not affect DNA extraction as seen in this study in both intervals which were suitable for amplification. More studies should be carried out on a larger scale to determine the effect of the various shades of tooth paste, mouth wash and alcohol consumption as it may cause a deleterious effect on buccal cell DNA.

\section{Acknowledgement}

We recognise the immense support of the staffs of the department of cell biology and genetics of the university of Lagos and also gratitude to the National Academy for the Advancement of Science for their support in grants and laboratory space for this research.

\section{References}

1. Anderson S, Bankier AT, Barrell BG, de Bruijn MH, Coulson AR, et al. (1981) Sequence and organization of the human mitochondrial genome. Nature 290: $457-65$.

2. Aquadro CF and Greenberg BD (1983) Human mitochondrial DNA variation and evolution: analysis of nucleotide sequences from seven individuals. Genetics 103: 287-312.

3. Armour JA, Povey S, Jeremiah S, Jeffreys AJ (1990) Systematic cloning of human minisatellites from ordered array charomid libraries. Genomics 8: 501-12.

4. Boerwinkle E, Xiong WJ, Fourest E, Chan L (1989) Rapid typing of tandemly repeated hypervariable loci by the polymerase chain reaction: application to the apolipoprotein B 3' hypervariable region. National Academic Science Journal USA, 86: 212-6.

5. Cai H, Caswell JL, Prescott JF (2014) Nonculture Molecular Techniques for Diagnosis of Bacterial Disease in Animals: A Diagnostic Laboratory Perspective. Veterinary Pathology 51: 341-50.

6. Cenchao S, Wenjuan Y, Qiaoli J, Hisaji M, Anjie D, Zhizhou Z (2009) NanoPCR observation: different levels of DNA replication fidelity in nanoparticleenhanced polymerase chain reactions. Nanotechnology 20: 455103.

7. Chamberlain JS, Gibbs RA, Ranier JE, Nguyen PN, Caskey CT (1989) Deletion screening of the Duchenne muscular dystrophy locus via multiplex DNA amplification. Nucleic Acids Res, 16: 11141-56.

8. Cheng S, Fockler C, Barnes WM, Higuchi R (1994) Effective Amplification of Long Targets from Cloned Inserts and Human Genomic DNA. Proceedings of the National Academy of Sciences 91: 5695-9.

9. Chien A, Edgar DB, Trela JM (1976) Deoxyribonucleic acid polymerase from the extreme thermophile Thermus aquaticus. Journal of Bacteriology $127: 1550-7$.

10. Cozier YC, Palmer JR, Rosenberg L (2004) Comparison of methods for collection of DNA samples by mail in the Black Women's Health Study. Annals of Epidemiology 2: 117-22. 
11. David F, and Turlotte E (1998) An Isothermal Amplification Method. Canadian Research Academic Science Life Science 321: 909-914.

12. de Vries HG, Collee JM, Veldhuizen MH, Achterhof L, Smit Sibinga CT, et al. (1996) Validation of the determination of deltaF508 mutations of the cystic fibrosis gene in over 11000 mouthwashes. Human Genetics 3: 334-336.

13. Don RH, Cox PT, Wainwright BJ, Baker K and Mattick JS (1991) 'Touchdown' PCR to circumvent spurious priming during gene amplification”. Nucleic Acids Restriction 19: 4008.

14. Edwards A, Civitello A, Hammond HA, Caskey CT (1991) DNA typing and genetic mapping with trimeric and tetrameric tandem repeats. American Journal Human Genet 49: 746-756.

15. Feigelson HS, Rodriguez C, Robertson AS, Jacobs EJ, Calle EE, et al. (2001) Determinants of DNA yield and quality from buccal cell samples collected with mouthwash. Cancer Epidemiology Biomarkers Preview 9: 1005-1008.

16. Garibyan L and Avashia N (2013) Polymerase Chain Reaction. J Invest Dermatol 133: 23-27.

17. Greenberg BD, Newbold JE and Sugino A (1983) Intraspecific nucleotide sequence variability surrounding the origin of replication in human mitochondrial DNA. Gene 21: 33-49.

18. Herman JG, Graff JR, Myöhänen, S, Nelkin BD and Baylin SB (1996) Methylation-specific PCR: a novel PCR assay for methylation status of CpG islands. Proc National Academic Science USA 93: 9821-6.

19. Horton RM, Hunt HD, Ho SN, Pullen JK and Pease LR (1989) Engineering hybrid genes without the use of restriction enzymes: gene splicing by overlap extension. Gene 77: 61-68.

20. Innis MA, Myambo KB, Gelfand DH, Brow MA (1988) DNA sequencing with Thermus aquaticus DNA polymerase and direct sequencing of polymerase chain reaction-amplified DNA. Proc National Academic Science USA 85: 9436-4940.

21. San Millan RM, Martinez-Ballesteros I, Rementeria A, Garaizar J, Bikandi J (2013) Online exercise for the design and simulation of PCR and PCR-RFLP experiᄀments. British Medical Council Research Notes 6: 513.

22. Sarkar G, Kapelner S, Sommer S (1990) Formamide can dramatically improve the specificity of PCR. Nucleic Acids Research $18: 7465$.

23. Trevilatto PC, Line SR (2000) Use of buccal epithelial cells for PCR amplification of large DNA fragments. Journal of Forensic Odontostomatology 1: 6-9.

24. Joseph S and David WR (2001) Molecular Cloning: A Laboratory Manual (3rd ed) Cold Spring Harbor, N.Y.: Cold Spring Harbor Laboratory Press.

25. Kellogg D E, Rybalkin I, Chen S, Mukhamedova N, Vlasik T, et al. (1994) TaqStart Antibody: hot start PCR facilitated by a neutralizing monoclonal antibody directed against Taq DNA polymerase. Biotechnology Techniques 16: 1134-7.

26. Khan Z, Poetter K, Park DJ (2008) Enhanced solid phase PCR: mechanisms to increase priming by solid support primers. Analytical Biochemistry 375: $391-393$. 27. Lawton G, Thomas S, Schonrock J, Monsour F, Frazer I (1992) Human papillomaviruses in normal oral mucosa: a comparison of methods for sample collection. Journal of Oral Pathology and Medicine 6: 265-9.

28. Lawyer F, Stoffel S, Saiki R, Chang S, Landre P, et al. (1993) High-level expression, purification, and enzymatic characterization of full-length Thermus aquaticus DNA polymerase and a truncated form deficient in 5' to 3' exonuclease activity. PCR methods and applications 2: 275-287.

29. Litt M, and Luty JA (1989) A hypervariable microsatellite revealed by in vitro amplification of a dinucleotide repeat within the cardiac muscle actin gene. American Journal Human Genetics 44: 397-401.

30. Merryweather-Clarke AT, Liu, YT, Shearman JD, Pointon JJ, Robson KJ (1997) A rapid non-invasive method for the detection of the haemochromatosis SC282Y mutation. British Journal Haematology 2: 460-463.

31. Moller S (2006) PCR (THE BASICS). US: Taylor \& Francis Group.

32. Mulot C, Stucker I, Clavel J, Beaune P, Loriot MA (2005) Collection of human genomic DNA from buccal cells for genetics studies: comparison between cytobrush, mouthwash, and treated cardiology. Journal Biomedical Biotechnology 3: 291-296.

33. Myrick KV and Gelbart WM (2002) Universal Fast Walking for direct and versatile determination of flanking sequence. Gene 284: $125-131$.

34. Nakamura Y, Leppert M. O’Connell P, Wolff R, Holm T, Culver M, et al. (1987) Variable number of tandem repeat (VNTR) markers for human gene mapping. Science 235: 1616-22.

35. Newton CR, Graham A, Heptinstall LE, Powell SJ, Summers C, et al. (1989) Analysis of any point mutation in DNA. The amplification refractory mutation system (ARMS). Nucleic Acids Research 17: 2503-16.

36. Park DJ (2004) 3'RACE LaNe: a simple and rapid fully nested PCR method to determine 3'-terminal cDNA sequence. Biotechnology techniques 36: 586-588.

37. Pavlov AR, Pavlova NV, Kozyavkin SA, Slesarev AI (2004) Recent developments in the optimization of thermostable DNA polymerases for efficient applications. Trends in Biotechnology 22: 253-260.

38. Pierce KE and Wangh LJ (2007) Linear-after-the-exponential polymerase chain reaction and allied technologies Real-time detection strategies for rapid, reliable diagnosis from single cells. Methods in Molecular Medicine 132: 65-85.

39. Q Chou M, Russell DE, Birch J (1992) Prevention of pre-PCR mis-priming and primer dimerization improves low-copy-number amplifications. Nucleic Acids Research 20: 1717-1723.

40. Raoult DG, Aboudharam E, Crubezy G, Larrouy B, Ludes M D (2000) Molecular identification by “suicide PCR" of Yersinia pestis as the agent of medieval black death. National Academic Science USA 97: 12800-03.

41. Royle NJ, Clarkson RE, Wong Z, Jeffreys AJ (1988) Clustering of hypervariable minisatellites in the proterminal regions of human autosomes. Genomics 3: 352-360.

42. Rychlik W, Spencer WJ, Rhoads RE (1990) Optimization of the annealing temperature for DNA amplification in vitro. Nucleic Acids Research 18: 6409-6412. 43. Saiki RK, Scharf S, Faloona F, Mullis KB, Horn GT, et al. (1985) Enzymatic amplification of beta-globin genomic sequences and restriction site analysis for diagnosis of sickle cell anemia. Science 230: 1350-4.

44. Salis AD (2009) Applications in Clinical Microbiology. Real-Time PCR: Current Technology and Applications. Caister Academic Press.

45. Isenbarger TA, Finney M, Ríos-Velázquez C, Handelsman J and Ruvkun G (2008) Miniprimer PCR, a New Lens for Viewing the Microbial World. Applied and Environmental Microbiology 74: 840-9.

46. Jeffreys AJ, Brookfield JF, Semeonoff R (1985) Positive identification of an immigration test-case using human DNA fingerprints. Nature 317: 818-819. 
47. Sharkey DJ, Scalice ER, Christy KG, Atwood SM, Daiss JL (1994) Antibodies as Thermolabile Switches: High Temperature Triggering for the Polymerase Chain Reaction. Biomedical Technology 12: 506-9.

48. Shen, Cenchao (2013) An Overview of Nanoparticle-Assisted Polymerase Chain Reaction Technology. US: Wiley-Blackwell Publishing Limited.

49. Stemmer WP, Crameri A, Ha KD, Brennan TM, Heyneker HL (1995) Single-step assembly of a gene and entire plasmid from large numbers of oligodeoxyribonucleotides. Gene 164: 49-53.

50. Jeffreys AJ, Neumann R, Wilson V (1990) Repeat unit sequence variation in minisatellites: a novel source of DNA polymorphism for studying variation and mutation by single molecule analysis. Cell 60: 473-485.

51. Vincent M, Xu Y, and Kong H (2004) Helicase-dependent isothermal DNA amplification. EMBO Reports 5: 795-800.

52. Wyman A, White RL (1980) A highly polymorphic locus in human DNA. Procreational Nationall Academic Science USA 77: 6754-6758.

53. Liu YG, and Whittier RF (1995) Thermal asymmetric interlaced PCR: automatable amplification and sequencing of insert end fragments from P1 and YAC clones for chromosome walking. Genomics 25: 674-81.

54. Zietkiewicz A, Rafalski D, Labuda (1994) Genome fingerprinting by simple sequence repeat (SSR)-anchored polymerase chain reaction amplification. Genomics 20: $176-83$. 